\section{Origin of metalliferous sediments}

For reasons which are largely historical and political rather than scientific, the first specific phenomenon likely to come to mind at any general mention of ocean mineralisation is that of manganese nodules. No doubt there is some justification for this emphasis, for in spite of the many unsolved problems relating to both their collection and processing, nodules will almost certainly be the first deep sea minerals to be exploited commercially. But nodules are not the whole story of marine mineralisation, nor, as Bullard (Endeavour, 33, 80; 1974) has pointed out, will they necessarily prove to be the most important part of it in the long run. Nodules are attractive because they are discrete conglomerations of a few metals in a particularly concentrated form, but in both economic and scientific terms they are likely to be rivalled increasingly by sediments containing unusually high proportions of similar elements.

The story of the discovery of metalrich sediments begins in 1948 when Swedish workers on the research vessel Albatross discovered a region of abnormally high temperature in the Red Sea just north of latitude $21^{\circ} \mathrm{N}$. About 15 years later, more detailed investigations of water temperature and salinity were carried out in the same region by teams from the United States, Germany and Britain; and as a result of the discoveries made then, a further study of both water and underlying sediments was undertaken in 1966 by the research vessel Chain from the Woods Hole Oceanographic Institution. These expeditions found three deep basins containing hot water with a salinity about seven times greater than that of normal Red Sea water. The largest of these 'brine pools' was the Atlantis II Deep (about $15 \mathrm{~km}$ long by $5 \mathrm{~km}$ wide), although it became clear that this is not the deepest of the brine-filled basins when Backer and Schoell (Nature phys. Sci., 240,$153 ; 1972$ ) reported the discovery of 13 more brine pools by the German ships Wando River and Valdivio.

But if the water in the Red Sea deeps is remarkable, equally so are the sediments beneath them. For whereas the normal sediments in the central trough of the Red Sea are lightcoloured marls, those in the brine pools were found to comprise yellow, red, brown and blue layers enriched in such metals as iron, manganese, copper and zinc. The enrichment seems to be high but quite variable. In 1969 Bischoff (in Hot Brines and Recent Heavy Metal Deposits in the Red Sea, Springer-Verlag, 1969) said that the high grade sediments in the Atlantis II Deep contain an average of $3.4 \% \mathrm{Zn}$ and $1.3 \% \mathrm{Cu}$ after removal of salt and water. But Tooms (Endeavour, 31, 113; 1972) has quoted a more recent survey by a commercial company which led to average estimates over a much wider area of $6 \% \mathrm{Zn}$ and "several per cent" $\mathrm{Cu}$. Even more recently, Backer and Schoell have claimed that some facies contain $50-65 \%$ iron, that the average manganese concentration in the Chain Deeps is $30-40 \%$ and that some sulphide layers in the Atlantis II Deep contain $20 \%$ zinc, although they admit that "continuously changing facies conditions" reduce the average base metal content to a few per cent.

But although quoted metal concentrations differ, there is complete agreement that enrichment has taken place; and this inevitably raises the question of how and under what circumstances it occurred. The Red Sea is widely believed to be an embryo ocean, and the deeps containing hot brine are closely associated with the central trough. The connection between metallogenesis and seafloor spreading is thus unmistakable-but is metal enrichment a feature only of spreading in its early stages or does it occur whenever and wherever spreading takes place? The thick salt deposits covering a large part of the Red Sea depression must be the ultimate source of the salt in the brine pools, and the brine pools are closely associated with the enriched sediments beneath. Does this mean that metal enrichment only takes place in relatively closed oceans conducive to the formation of salt deposits by repeated evaporation, or is the presence of abundant salt in itself an unnecessary condition?

These questions cannot yet be properly answered. But there is now abundant evidence for the existence of metal-rich sediments on the East Pacific rise and other ocean ridges. Such sediments were apparently known to Revelle (Publs Carnegie Instn., 556; 1944) thirty years ago, although modern studies can probably be said to date from the geochemical work of Bostrom and Peterson (Econ. Geol., 61, 1258; 1966) following the discovery of the critical part played by ocean ridges in global tectonics. In this and numerous subsequent reports, Bostrom and his colleagues and others have shown that metal enrichment (but not apparently to economic concentrations) does indeed take place along ridges in late stages of spreading; and Deep Sea Drilling Project results have indicated that such sediments are not uncommon at the base of sedimentary columns throughout the ocean basins.

The general circumstances in which metalliferous sediments are likely to form are thus at least partly understood; but precisely how they form is still an unsolved problem. Nevertheless, it is becoming increasingly clear that hydrothermal processes are involved in some way. In the case of the Red Sea, for example, it may be presumed that the salt in the brine comes from the existing salt deposits, but the water must have acquired its temperature from the upwelling magma at the central rift. It is then reasonable to suppose that, during contact with the magma, the water also acquired metallic components which later precipitated out as metallic compounds to form the observed sedimentary ores.

In fact, water may well penetrate to substantial depths (possibly several kilometres) in the new oceanic crust at ridge axes, thus leaching a considerable volume of rock. Both Corliss ( $J$. geophys. Res., 76, 8128; 1971) and Spooner and Fyfe (Contr. Mineral. Petrol., 42, 287; 1973) have proposed models in which sedimentary metal enrichment could occur by this mechanism; and Lister (Geophys. J., 26, $515 ; 1972)$ has used deep hydrothermal circulation to explain the unexpectedly low average heat flow at ridge crests and the high scatter of heat flow values at ridge crests and flanks. Piper (Earth planet. Sci. Lett., 19, 75; 1973) and many others have offered geochemical evidence; and on page 473 of this issue of Nature, Anderson and Halunen present combined geophysical and geochemical data which give further support. As Lister (Eos, 55, 740; 1974) has rightly suggested, what is required now is a commitment to test the hydrothermal circulation hypothesis more directly by deep sea borehole measurements.

Peter J. SMith

\section{Cell culture pharmacology}

\section{from Mary Dawson}

THE action of drugs on cultured vertebrate cells was the subject of tha autumn meeting of th. British Society for Cell Biology, held at the University of Strathclyde, Glasgow, on September 19 and 20, 1974. Most of the experiments described had one of four main objects - to increase knowledge of the cells being studied by using known compounds as tools, to elucidate the mode of action of drugs where this was unknown or partly known, or to design in vitro tests which would either provide knowledge about new drugs under development or would form a basis 